\title{
Green Standard Model Using Machine Learning: Identifying Threats and Opportunities Facing the Implementation of Green Building in Iran
}

\section{Mohamad Rajabi}

Islamic Azad University

Javad Majrouhi Sardroud ( $\nabla$ j.majrouhi@gmail.com )

Islamic Azad University

Ali Kheyroddin

Semnan University

\section{Research Article}

Keywords: Green standard, machine learning, energy consumption, environmental pollution, Iran

Posted Date: March 25th, 2021

DOI: https://doi.org/10.21203/rs.3.rs-213367/v1

License: (c) (i) This work is licensed under a Creative Commons Attribution 4.0 International License.

Read Full License

Version of Record: A version of this preprint was published at Environmental Science and Pollution Research on July 2nd, 2021. See the published version at https://doi.org/10.1007/s11356-021-14991-3. 


\title{
Green Standard Model Using Machine Learning: Identifying Threats and Opportunities Facing the Implementation of Green Building in Iran
}

\author{
Mohamad Rajabi ${ }^{1}$, Javad Majrouhi Sardroud ${ }^{*}$, Ali Kheyroddin ${ }^{3}$ \\ ${ }^{1}$ Ph.D. Researcher, Department of Civil \& Construction Engineering, Central Tehran Branch, \\ Islamic Azad University, Tehran, Iran \\ ${ }^{2}$ Assistant Professor, Department of Civil \& Construction Engineering, Central Tehran Branch, \\ Islamic Azad University, Tehran, Iran \\ ${ }^{3}$ Distinguished Professor, Department of Civil Engineering, Semnan University, Semnan, Iran \\ *Corresponding Author Email: j.majrouhi@gmail.com
}

\section{Abstract}

Residential buildings consume a major portion of energy resources and hence are seriously involved in environmental pollution. In Iran, the consumption of fossil fuels is on the rise, to the extent that it has grown by more than $400 \%$ from 1990 to 2018 . One of the fundamental solutions for reducing fossil fuel consumption and creating a healthy environment inside and outside buildings is the implementation and development of green buildings. This study seeks to examine the obstacles and opportunities facing green building and proposes a localized green standard befitting the conditions of Iran with the aim of contributing to the development of green buildings. To this end, the requisite parameters were identified using the opinions of experts and Delphi method, and the opinions of 81 building experts including the employer, consultant and contractor were obtained using a three-part questionnaire. Based on the results obtained using the machine learning method, the score of the local green building in a total of five dimensions, namely site, water, energy, materials and quality of indoor environment was calculated to be 77.2, while the energy dimension was determined to be the most important green standard dimension with a significance coefficient of 0.548 . In the ranking analysis of all parameters using Friedman test, the parameters of energy consumption management, use of renewable energy and thermal zoning attained the highest scores among other factors. 
29 Furthermore, lack of awareness on green buildings (77\%) and high potential for renewable energy production $(81 \%)$ were respectively identified as the biggest obstacle and opportunity facing the

31 implementation of green buildings in Iran.

Keywords: Green standard, machine learning, energy consumption, environmental pollution, Iran

\begin{tabular}{|ll|}
\hline \multicolumn{2}{l|}{ Abbreviations } \\
LEED & Leadership in Energy and Environmental Design \\
BREEAM & Building Research Establishment Environmental Assessment Method \\
CASBEE & Comprehensive Assessment System for Building Environmental Efficiency \\
ITACA & In English: Institute for Transparency of Contracts and Environmental Compatibility, Italy \\
DGNB & In English: German Sustainable Building Council \\
ASGB & Assessment Standard for Green Buildings \\
SB Tool & Sustainable Building Tool \\
GBL & Green Building Label \\
GM & Green Mark \\
GS & Green Star \\
\hline
\end{tabular}

\section{Introduction}

Climate change and the gradual process of global warming are among the serious threats and challenges facing different societies that is directly related to the consumption of fossil fuels and carbon dioxide production (Mirzaei and Bekri, 2017; Sarwar and Alsaggaf, 2020). The everincreasing demand for exploration and exploitation of natural resources in different countries has resulted in devastating environmental impacts (Balaban and Oliveira, 2017). The complications of

41 increasing pollution and climate change have long been accounted by scientific evidence and various studies, as approximately $20 \%$ of pollution and greenhouse gas emissions are attributed to residential buildings, which are a significant part of carbon emissions in the environment (Zhang et al, 2018; Cordero et al, 2019). Buildings often require special attention given their high energy consumption and their role in creating environmental challenges, as they account for about 20 to $50 \%$ of global energy consumption and more than $40 \%$ of solid waste production (Dwaikat and Ali, 2016;

47 MacNaughton et al, 2018; Kim et al, 2014). In China, about $60 \%$ of carbon dioxide emissions and in 
48 the United States and the EU, 35 to $40 \%$ of carbon dioxide emissions are attributed to residential buildings (Sinha et al, 2013; Li et al, 2014).

50 Energy consumption is reportedly excessive in Iran, which has resulted in threatening consequences

51 for various economic, political and environmental aspects (Taghvaee et al, 2017). Iran is a rich country in oil and gas energy resources, holding $11 \%$ of world's oil reserves and $15.3 \%$ of the natural gas reserves, where energy is mainly produced using fossil fuels. Unfortunately, the pattern of energy consumption in Iran is highly inefficient and many factors such as low energy prices, energy subsidies, high population rates, economic growth and poor resource management have also resulted in a sharp increase in energy consumption, high carbon dioxide production as well as environmental pollution (Moshiri et al, 2012; Hosseini et al, 2013). Energy consumption in Iran has increased by $415 \%$ from 1990 to 2018 , that is from 53 to 273 TWh, while also the amount of carbon dioxide emissions has increased by $238 \%$, from 171 to about 580 million tons, During the same period (IEA, 2018; EIA, 2018) and is projected to increase with annual growth of 5\% to about 985 million tons by 2025 (Mirzaei and Bekri, 2017).

Widespread concerns regarding high energy consumption, global warming, and depletion of nonrenewable energy sources have led to development of green building movement (Esa et al, 2011). Green buildings have been proposed as one of the most efficient and ideal solutions for sustainable and healthy buildings, optimal use of resources, increasing the recycling capacities of construction materials, and hence has been proposed as an approach to alleviate environmental challenges (Nguyen et al, 2017; Zuo et al, 2017). Green buildings greatly contribute to mitigation of the harmful effects on the environment, economy and people (Neyestani, 2017), in which increased energy efficiency and renewable energy are employed to significantly reduce the consumption of fossil fuels (Eliasa and Lin, 2015). In recent years, the existence of some incentives or government subsidies in some countries is one of the factors that has led many small contractors to build and develop green buildings (Shan et al, 2020). Studies indicate that the significance of and the ensuing interest in green 
73 buildings is rapidly growing in many countries around the globe, and some developed countries such as the United States, the United Kingdom, Singapore, Hong Kong, Australia and Italy have taken major strides in the development of green buildings, while developing countries such as Colombia, the construction and development of green buildings worldwide (Qifa, 2013).

Huo and Yu (2017) examined the benefits of green buildings from 2007 to 2016 and reported that

Egypt and China have also sought to develop green building research (Darko and Chan, 2016). As the understanding of the concept of green building development grows all around the world, the notion of green construction has been widely expanding, and more attention is now being given to green buildings are more environmentally-friendly, conserve energy, and provide better performances in terms of thermal comfort, indoor air quality and noise pollution. Green buildings have many positive environmental, social and economic consequences and contribute to national economy and gross domestic product (GDP), effects of which gain more prominence over time (Zuo and Zhao, 2014; Zhao et al, 2019). Although the initial costs of green buildings are higher than those of conventional buildings, they hold a plethora of advantages, such as the use of renewable energy, rainwater recycling, and environmentally friendly material, outweighing the costs (Khot et al, 2019; Lee et al, 2013). MacNaughton et al. (2018) studied the benefits of implementing green buildings in six countries, namely the United States, China, India, Brazil, Germany and Turkey, the results of which revealed that implementing green buildings in the aforementioned countries has saved $\$ 7.5$ billion in energy consumption and has prevented 33 million tons of carbon dioxide emission into the atmosphere. (Nangare et al, 2015) also revealed the implementation of green buildings has reduced energy consumption by at least $25 \%$ in China. In Turkey, green buildings with platinum and gold certification have respectively save $40 \%$ and $31 \%$ in energy consumption, respectively (Ŭgur and Leblebici, 2018). Implementation of green buildings in Israel has reduced water and electricity consumption respectively by $24 \%$ and $23 \%$ compared to those in conventional buildings (Meron and Meir, 2017). Dwaikat and Ali (2018) reported that implementing green buildings in Malaysia has 
98 reduced energy consumption by 28.9\%, while Ebadati and Ehyaei (2018) been reported that implementing green ceilings in Iran reduces energy consumption by $17 \%$.

Despite the widespread benefits of green buildings, their implementation has been faced with many challenges and obstacles in some countries. Darko and Chan (2017) reviewed the literature on green buildings, and identified lack of information, high cost, lack of motivation, and lack of demand, interest and regulations of green buildings as the most significant threats to the implementation of green buildings. Esa et al. (2011) reported lack of education and lack of awareness regarding the benefits of green buildings, and Samari et al. (2013) identified the lack of credit resources, high investment risk, lack of demand and high costs as the greatest obstacles to the implementation of green buildings. Based on the results $\mathrm{Li}$ et al. (2014), three factors of lack of awareness on the stakeholder side, lack of research and non-favorable existing laws have been identified as the most important threats to the development of green buildings in China (Li et al, 2014). In Thailand, lack of motivation from landlords, high initial costs and financial and technical constraints (Shen et al, 2018), in Saudi Arabia, lack of government support and lack of skilled labor (Mosly, 2015), and in

Ghana, high costs, lack of government incentives, and lack of financial plans have been identified as the biggest obstacles to implementation of green buildings (Chan et al, 2018).

The implementation of green rating systems for the evaluation of buildings is of paramount importance increase awareness of sustainable development in the construction industry and help thus reduce environmental pollution (Hedaoo and Khese, 2016; Cordero et al, 2019). Environmental evaluation methods are one of the most prevailing and efficient instruments to enhance the performance of buildings and in the last decade, a plethora of assessment standards have been published or are under development around the world (Amos and Chan, 2016). Some of the green building rating systems include LEED (US), BREEAM (UK), CASBEE (Japan), GS (Australia), BEAM PLUS (Hong Kong), GM (Singapore), DGNB (Germany), GBL (China) and SB Tool are multinational organizations established for different types of residential buildings (that is, detached 
123 houses and apartments), schools, hospitals, office buildings, and industrial buildings among others 124 (Alyami and Rezgui, 2012; Zuo and Zhao, 2014 Gou and Xie, 2017). The BREEAM standard, 125 launched in 1990, is recognized as the world's first residential building rating assessment, followed 126 by the pilot version of the LEED standard in 1998 (Doan et al, 2017). Mattoni et al. (2018) compared 1275 well-known standards of LEED, BREEAM, Green Star, CASBEE and ITACA, the result of which 128 reveal that, except for the CASBEE standard, in which comfort and safety are given the highest 129 importance, the highest ratings in other standards are attributed to energy consumption. Moreover, 130 Cordero et al. (2019) examined the application of different standards among EU countries and 131 reported that $65 \%$ of EU housing projects employ the UK BREEAM standard, $6.49 \%$ are based on 132 the German DGNB standard, 5.46\% are based on the LEED standard, and the rest have employed 133 other standards.

134 Unfortunately, unlike many developed countries, Iran is yet to develop a green standard, and given 135 that the green standard of each country is developed tailored to the conditions and regulations of that 136 country, employing green standards of other countries is not recommended for Iran, and each country 137 should develop green building standards according to the laws, instructions and climatic conditions, 138 and only after identifying the existing opportunities and threat therein. Hence, based on the 139 aforementioned discussion, the purpose of the current study was to provide an overview on the 140 opportunities and obstacles of implementing green buildings in Iran based on different viewpoints 141 from employers, consultants and contractors, discusses the need to implement green buildings owing 142 to excessive consumption of fossil fuels and the high potential of using renewable energy, provide a 143 localized green standard model tailored to the conditions of the Iran using 6 widely used standards of 144 LEED, BREEAM, CASBEE, GS, BEAM PLUS and ASGB, and ultimately, seeks to predict total 145 score and rank the relevant items. Findings of this study can contribute to knowledge of green 146 building localization in Iran and can have implications for contractors, investors and decision makers 147 in the construction and energy sector with the aim of paving the way for development of green 
buildings. It can also pose as a useful reference for international organizations seeking to develop solutions to alleviates obstacles to and increase the potential of green buildings.

\section{Research method}

151 For the purposes of this study, 14 experts with postgraduate education in the fields of civil 152 engineering, architecture, electricity and mechanics who had the criteria of knowledge and 153 experience, sufficient opportunities and effective communication skills in the field of research 154 formed the Delphi research panel. In the first part of the research, 8 obstacles and 5 155 opportunities/necessities of implementing green building in Iran were identified by the panel, and in 156 the second part, 6 widely used green standards in the world, namely LEED, BREEAM, CASBEE, 157 GS, ASGB and BEAM PLUS, which had partial similarities with the conditions in Iran, were examined to help identify national items for green building. After reviewing the items within the 6 standards, experts were able to comment, and hence delete, edit or add new items appropriate to the conditions of Iran, and ultimately, 67 green standard parameters were identified in accordance with 161 the conditions of Iran in 5 dimensions of the site, water, energy, materials and the quality of the 162 indoor environment.

\subsection{Questionnaire}

A 3-part questionnaire with the issues of localized green standard items, obstacles and opportunities/necessities of implementing green building in Iran was developed and the respondents were asked to give their opinions and score the items using a 5-level Likert scale, ranging from zero (insignificant) to 4 (with high importance). The questionnaires were proven to have proper validity and reliability and Cronbach's alpha coefficient for national green standard items was 0.715 , for green building obstacles was 0.772 , and for opportunities/necessities of implementing green building was 0.778 . In this study, 110 questionnaires were distributed among the statistical population of contractors, employers and consultants, from which 81 questionnaires were completed and returned.

172 The characteristics of the respondents are presented in Table 1. The inclusion criteria were having an 
173 education level of bachelor's degree to $\mathrm{PhD}$ in the fields of civil engineering, mechanics, electricity 174 and architecture, working experience in the field of construction and high familiarity with 175 construction industry projects. descriptive statistical method (central tendency and dispersion) was 176 employed to rank the items of the inventory for obstacles and opportunities of implementing green 177 building, while Friedman test in SPSS was used to rank items of green building standard.

Table 1: Background information of the respondents

\begin{tabular}{|c|c|c|c|c|c|c|c|c|c|}
\hline \multirow{3}{*}{ Characteristics } & \multirow{3}{*}{ Frequency } & \multirow{3}{*}{ Percent } & \multicolumn{7}{|c|}{ Years of Experience } \\
\hline & & & \multicolumn{4}{|c|}{ construction industry } & \multicolumn{3}{|c|}{ green buildings } \\
\hline & & & $1-5$ & $6-10$ & $10-20$ & $\begin{array}{l}\text { More } \\
\text { than } 20\end{array}$ & $1-2$ & $3-5$ & $\begin{array}{l}\text { More } \\
\text { than } 5\end{array}$ \\
\hline \multicolumn{10}{|l|}{ Field of education } \\
\hline Civil & 39 & 48.2 & 2 & 9 & 18 & 10 & 23 & 11 & 5 \\
\hline mechanical & 23 & 28.4 & 2 & 5 & 11 & 5 & 12 & 6 & 5 \\
\hline electrical & 12 & 14.8 & 2 & 2 & 5 & 3 & 8 & 3 & 1 \\
\hline Architectural & 7 & 8.6 & 3 & 1 & 3 & 0 & 4 & 3 & 0 \\
\hline $\begin{array}{l}\text { Subtotal } \\
\text { Job Type }\end{array}$ & 81 & 100 & 9 & 17 & 37 & 18 & 47 & 23 & 11 \\
\hline Employer & 26 & 32.1 & 6 & 5 & 10 & 5 & 15 & 7 & 4 \\
\hline Consultant & 17 & 20.9 & 2 & 3 & 8 & 4 & 8 & 5 & 4 \\
\hline Contractor & 38 & 47 & 1 & 9 & 19 & 9 & 24 & 11 & 3 \\
\hline Subtotal & 81 & 100 & 9 & 17 & 37 & 18 & 47 & 23 & 11 \\
\hline
\end{tabular}

\subsection{Machine Learning}

182 Machine learning (ML) is a type of artificial intelligence (AI) which seeks to develop applications 183 that can learn and progress without being explicitly programmed to do so. Machine learning is in fact 184 consisted of various algorithms and statistical models used by computer systems instead of explicit 185 instructions (Everitt and Hothorn, 2011). One of the most important branches of machine learning is 186 multivariate analysis methods, in which several variables in the data set are reviewed and analyzed 187 simultaneously. Two highly groundbreaking methods among multivariate analysis methods are 188 exploratory factor analysis (EFA) and principal component analysis (PCA). In this research, PCA 189 method and R software were used to predict or estimate the green building score. 
192 Eight major obstacles to the implementation of green buildings in Iran were identified by the expert 193 panel and thus evaluated by the respondents using a 5-point Likert scale, the results of which are 194 shown separately for employers, consultants and contractors in Table 2.

Table 2: Ranking the obstacles to the implementation of green buildings

\begin{tabular}{|cccccccccccccc}
\hline \multirow{2}{*}{ Items } & \multicolumn{3}{c}{ Overall } & \multicolumn{3}{c}{ Employer } & & Consultant & Contractor \\
\cline { 2 - 12 } & M. & SD & R. & M. & SD & R. & M. & SD & R. & M. & SD & R. \\
\hline Lack of awareness & 3.1 & .889 & 1 & 3.23 & 0.815 & 1 & 2.94 & 0.966 & 2 & 3.08 & 0.912 & 1 \\
High investment risk & 2.89 & 1.024 & 2 & 3.04 & 0.999 & 2 & 3.12 & 0.693 & 1 & 2.68 & 1.141 & 3 \\
Lack of economic justification & 2,74 & .946 & 3 & 2.38 & 0.941 & 3 & 2.94 & 0,899 & 3 & 2.89 & 0.924 & 2 \\
Lack of national green standard & 2.4 & 1.08 & 4 & 2.15 & 1.19 & 4 & 2.59 & 0.939 & 5 & 2.47 & 1.059 & 5 \\
Lack of government support & 2.38 & 1.056 & 5 & 2.04 & 1.183 & 6 & 2.65 & 0.931 & 4 & 2.5 & 0.98 & 4 \\
Lack of skilled labor & 2.25 & .929 & 6 & 2.11 & 0.952 & 5 & 2.29 & 0.849 & 8 & 2.32 & 0.962 & 8 \\
High initial cost & 2.22 & 1.084 & 7 & 1.92 & 1.129 & 7 & 2.41 & 0.939 & 6 & 2.34 & 1.097 & 7 \\
Lack of technology or services & 2.2 & 1.123 & 8 & 1.81 & 1.2 & 8 & 2.41 & 0.939 & 7 & 2.37 & 1.1 & 6 \\
Average & 2.52 & - & - & 2.34 & - & - & 2.67 & - & - & 2.58 & - & - \\
\hline
\end{tabular}

Note: M.= mean; R.= rank; $\mathrm{SD}=$ standard deviation; Cronbach's Alpha $=0.772$

197 As can be seen from Table 2 and Figure 1, the item with the highest rank according to the 198 respondents was the lack of awareness with a mean 3.1, which is consistent with the findings of 199 many different studies in the world (Darko and Chan, 2017; Esa et al, 2011, Li et al, 2014). Items 200 with the second and third highest ranks according to the respondents were respectively high 201 investment risk and lack of economic justification with respective means of 2.89 and 2.74. The 202 opinion of respondents from the 3 job groups (namely employer, consultant and contractor) slightly 203 diverges in ranking the evaluation indicators. All items on obstacles to green building have relatively 204 high scores with a minimum of 2.2, indicating that the implementation of green buildings in Iran is met with serious challenges and obstacles. 
Lack of skilled labor

Lack of technology or services

Lack of government support

Lack of economic justification

Lack of native green standard

High initial cost

High investment risk

Lack of awareness

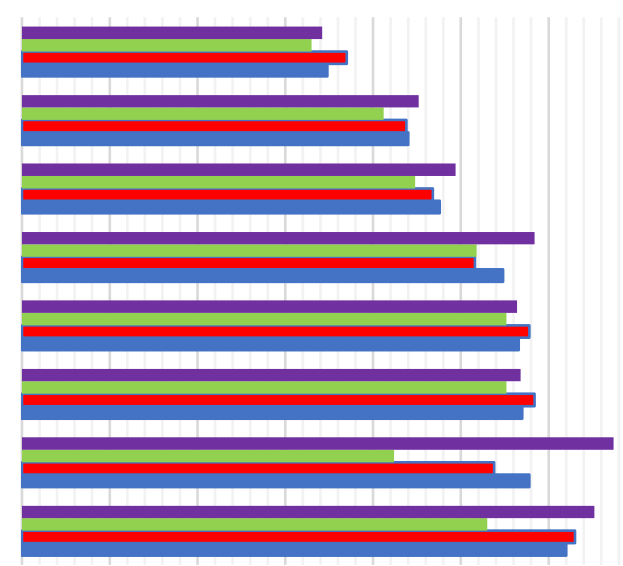

Contractor

Consultant

Employer

口overall

$\begin{array}{lllllllll}0 & 0.5 & 1 & 1.5 & 2 & 2.5 & 3 & 3.5 & 4\end{array}$

Figure 1: Obstacles to the implementation of green buildings in Iran

\subsection{Opportunities or necessities of implementing green buildings in Iran}

209 Respondents were asked about various indices for assessing the opportunities or necessities of 210 implementing green building in Iran, the results of which are shown in Table 3.

Table 3: Ranking opportunities or necessities of green building implementation

\begin{tabular}{|cccccccccccccc|}
\hline \multirow{2}{*}{ Items } & \multicolumn{4}{c}{ Overall } & \multicolumn{1}{c}{ Employer } & \multicolumn{4}{c|}{ Consultant } & \multicolumn{3}{c|}{ Contractor } \\
\cline { 2 - 12 } & M. & SD & R. & M. & SD & R. & M. & SD & R. & M. & SD & R. \\
\hline Renewable energy potential & 3.25 & 0.874 & 1 & 3.08 & 1.055 & 2 & 3.35 & 0.786 & 1 & 3.32 & 0.775 & 1 \\
High consumption of fossil fuels & 3.15 & 0.95 & 2 & 3.12 & 0.993 & 1 & 3.24 & 0.903 & 2 & 3.13 & 0.963 & 4 \\
Cheap manpower & 3.07 & 0.946 & 3 & 2.92 & 0.935 & 3 & 3.06 & 1.144 & 4 & 3.18 & 0.865 & 3 \\
High production of construction waste & 3.07 & 1.093 & 4 & 2.85 & 1.287 & 4 & 3.12 & 1.111 & 3 & 3.21 & 0.935 & 2 \\
Low annual rainfall & 2.88 & 1.279 & 5 & 2.65 & 1.355 & 5 & 3.06 & 1.088 & 5 & 2.95 & 1.314 & 5 \\
Average & 3.08 & - & - & 2.92 & - & - & 3.17 & - & - & 3.16 & - & - \\
\hline
\end{tabular}

Note: M.= mean; R.= rank; $\mathrm{SD}=$ standard deviation; Cronbach's Alpha $=0.778$ 


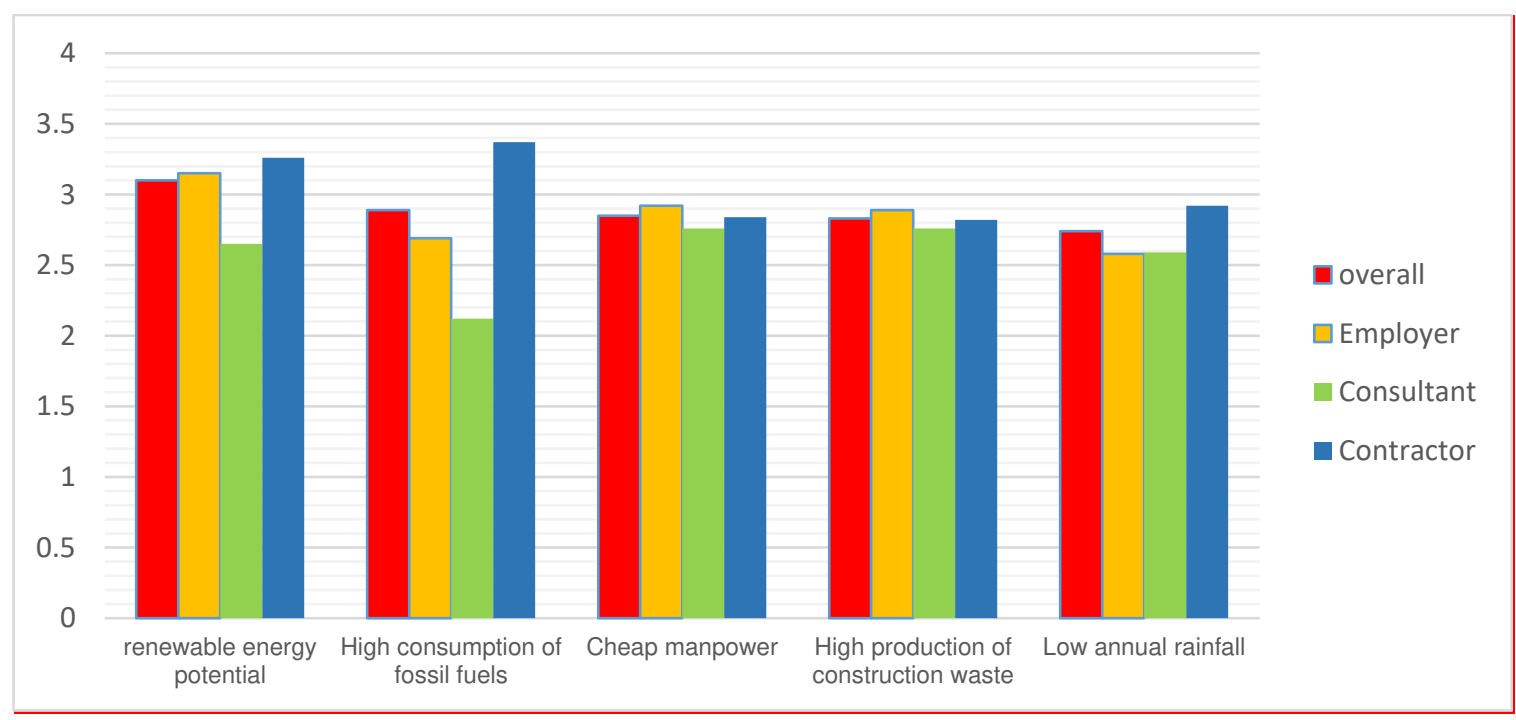

Figure 2: Opportunities or necessities of implementing green buildings in Iran

215 Based on the results obtained from Table 3 and Figure 2, the potential of renewable energy 216 production in Iran was ranked first with a score of 3.25 , followed by the the high consumption of 217 fossil fuels, which was ranked second with a score of 3.15 among other factors. The average score 218 obtained is significant and equal to 3.08, except for one item, the score of other items is higher or 219 approximately equal to the average of the results. Based on the obtained results, evaluation indicators 220 in all 3 occupational groups are of paramount significance, and hence a brief description is provided 221 for each item.

\section{3.2.1. Renewable energies}

223 Iran offers highly favorable conditions for the production of renewable solar and wind energy, as 224 about $60 \%$ of the land is desert which can receive maximum solar radiation. There are areas in Iran 225 where sunny hours are significant, that is, 1050 hours in summer, 700 hours in spring, 830 hours in 226 autumn and 500 hours in winter. Also, the presence of various tropical wind currents results in an 227 abundance of windy areas and fortunately Iran's wind sites have attained the highest-ranking classes 228 by the US Department of Energy (Ghorashi and Rahimi, 2011). Although the production of renewable energy and especially solar energy in Iran has increased in size in recent years, that is, 
more than 8 times from 2016 to 2019, this amount of energy in 2019 still stands at a very small value of about $367 \mathrm{MW}$, accounting for only $2 \%$ of the total energy produced in Iran (IRENA, 2019).

\subsubsection{High consumption of energy and fossil fuels}

233 Iran is one of the top ten producers of carbon dioxide in the world, while it has the most natural gas 234 reserves and the fourth most oil reserves in the world (Mousavi et al, 2017). Energy consumption in 235 Iran is increasing rapidly and most of the energy production is supplied by fossil fuels, to the extent 236 that in 2018, about $96 \%$ of energy in Iran is supplied from non-renewable sources such as oil and 237 natural gas (IEA, 2018). Energy consumption in Iran is 15 times that of Japan, 10 times that of the 238 European Union and 2.5 times that of other countries of Middle East, and with a growth rate of 3.2\%, 239 the construction industry has one highest annual energy growth, only second to the manufacturing 240 industry (EIA, 2018). The implementation of green buildings can provide a significant reduction in 241 fossil fuel consumption and hence carbon dioxide emissions.

\subsubsection{Cheap manpower}

243 Manpower is one of the most significant issues in the economic development of any country and the 244 optimal use of physical capital heavily relies on the human resources of that country (Sameei, 2012). 245 Due to the high initial cost of green buildings (Chen et al, 2011; Hwang and Tan, 2012), the cheap 246 manpower of the country offers a good potential for the implementation of green buildings. High 247 unemployment, high youth population, and abundance of foreign immigrants, who work mainly as 248 construction workers, have led to reduced construction wages.

\subsubsection{High production of construction waste}

250 Production of construction waste has rapidly increased in many countries with the increased trend of 251 urbanization, and has thus been acknowledged as one of the most serious environmental challenges 252 (Ding et al, 2018). The construction industry in Iran is considered as one of the largest waste production industries of the country (Eghbali et al, 2019), to the extent that only in Tehran from 2013 
254 to 2014, about 23 million tons of construction waste was produced, a small part of which was 255 recycled and the rest to were transferred to landfills (Nikmehr et al, 2015). Implementation of green 256 buildings can lead to the use of renewable materials, recycling of construction waste and reducing 257 the consumption of natural materials, all of which can contribute to the reduction of carbon dioxide 258 emissions and hence environmental pollution.

\subsubsection{Low mean annual rainfall}

260 Iran is located in one of the semi-arid regions of the world which has low rainfall as well as unequal 261 distribution of rainfall in different regions (Khozeymehnezhad and Tahroudi, 2019). Intermittent 262 droughts in recent years have led to serious challenges for drinking water supply in some cities, and 263 green buildings can provide ground optimal use of water, rainwater recycling and gray water 264 treatment.

\subsection{Ranking of different items of green standard}

266 For the localized green standard in Iran, 67 indicators were identified in a total of 5 dimensions, namely site, water, energy, materials and quality of indoor environment. After obtaining the results from the questionnaires, each dimension was ranked based on Friedman ranking test (Soleymani and Nik Nafs, 2017), the results of which is presented in Table 4.

Table 4: Suggested list of green standard parameters in Iran

\begin{tabular}{|c|c|c|c|}
\hline code & F. & R. & Activity description \\
\hline \multicolumn{4}{|l|}{ Site } \\
\hline $\mathrm{S} 2$ & 12.24 & 1 & $\begin{array}{l}\text { At least } 10 \text { different services such as bank, store, school, university, etc should be provided within a } \\
\text { maximum distance of } 500 \text { meters from the site }\end{array}$ \\
\hline S13 & 10.48 & 15 & The project is located in areas where residents can walk inside or outside the project \\
\hline S10 & 10.13 & 13 & The building is designed in accordance with the rules and preserves the historical landscape of the area \\
\hline S3 & 10.04 & 16 & At least 2 different recreational or sports facilities are provided within the site for the use of residents \\
\hline S5 & 9.79 & 14 & Provide places for parking bicycles and electric motorcycles \\
\hline S11 & 9.67 & 2 & Design green space on the roof that covers at least $50 \%$ of the roof area \\
\hline S9 & 9 & 3 & Build the building in areas that do not need to occupy new land \\
\hline S7 & 8.9 & 4 & The building is designed according to local laws for the physically disabled \\
\hline S6 & 8.64 & 5 & In the parking lot, there are places for parking cars for the disabled \\
\hline S15 & 8.29 & 6 & $\begin{array}{l}\text { Build the building in areas where the risk of flooding is low and there is a possibility of rapid discharge } \\
\text { of runoff (mandatory) }\end{array}$ \\
\hline
\end{tabular}




\begin{tabular}{|c|c|c|c|}
\hline $\mathrm{S} 1$ & 7.77 & 7 & The maximum distance of the building from one of the public transport networks is 500 meters \\
\hline S8 & 7.1 & 8 & Avoid selecting sites in agricultural areas or areas endangered by animal and plant species \\
\hline S14 & 6.81 & 9 & Landscaping and planting of suitable plants in the site has been done \\
\hline S4 & 5.85 & 11 & In the house there is a work room with convenient services such as internet, printer, desk, chair, etc. \\
\hline $\mathrm{S} 12$ & 5.72 & 10 & $\begin{array}{l}\text { Protect the ecological features of the land and prevent the destruction of existing trees during } \\
\text { construction }\end{array}$ \\
\hline S16 & 5.63 & 12 & In order to reduce the volume of runoff, various plans have been taken to direct or absorb surface water \\
\hline \multicolumn{4}{|l|}{ Water } \\
\hline W1 & 7.56 & 1 & $\begin{array}{l}\text { Drinking water consumption should be managed so that the average water consumption in a one-year } \\
\text { period is at least } 25 \% \text { less than the normal consumption of the city or region under study }\end{array}$ \\
\hline W5 & 6.78 & 2 & There is the necessary equipment to collect and recycle rainwater in the project \\
\hline W9 & 6.51 & 6 & Use leak detection systems that are able to detect major water leaks \\
\hline W7 & 6.46 & 3 & At least $50 \%$ of wastewater is treated and used for non-drinking purposes \\
\hline W3 & 6.19 & 4 & All faucets are equipped with water saving facilities \\
\hline W10 & 5.99 & 5 & Water consumption monitors have been installed for bathrooms, kitchens, and toilets \\
\hline W2 & 5.01 & 7 & In the building, sanitary components and drinking needs are separated from non-drinking needs \\
\hline W4 & 4.07 & 8 & Installation of efficient valves and devices in water that have a grade A or B efficiency label design \\
\hline W6 & 3.98 & 9 & The quality of drinking water in the building is good and has the necessary standards \\
\hline W8 & 2.44 & 10 & Drip irrigation has been used to irrigate the yard and green space \\
\hline \multicolumn{4}{|c|}{ Energy } \\
\hline E1 & 7.81 & 1 & $\begin{array}{l}\text { The location of the building, the dimensions of the windows, the thermal insulation and in general the } \\
\text { energy design of the building should be done in such a way that the estimated energy consumption of the } \\
\text { building using simulation is at least } 20 \% \text { lower than the energy consumption of similar non-green } \\
\text { buildings }\end{array}$ \\
\hline E6 & 7.31 & 2 & Use green and renewable energy to provide at least $5 \%$ of total energy \\
\hline E2 & 6.23 & 3 & $\begin{array}{l}\text { In order to encourage consumption reduction, the average electricity consumption of a building over a } \\
\text { one-year period should be at least } 25 \% \text { less than the normal consumption of the city or area under study }\end{array}$ \\
\hline E4 & 6.19 & 7 & In the building, energy consumption display systems have been used in different parts of the building \\
\hline E10 & 6.17 & 4 & $\begin{array}{l}\text { In order to encourage consumption reduction, the average gas consumption of the building in the period } \\
\text { of one year has been studied and should be at least } 25 \% \text { less than the normal consumption of the city or } \\
\text { region under study }\end{array}$ \\
\hline E5 & 5.76 & 9 & If the equipment is not optimally operated, alarm systems have been used to users \\
\hline E9 & 5.21 & 5 & $\begin{array}{l}\text { The outer shell of the building, including the walls, ceiling and floor, is made of suitable thermal } \\
\text { insulation }\end{array}$ \\
\hline E8 & 4.65 & 6 & $\begin{array}{l}\text { Intelligent disconnection and connection system has been used in heating and cooling systems of the } \\
\text { building }\end{array}$ \\
\hline E7 & 3.51 & 8 & At least $80 \%$ of energy devices and equipment must have energy consumption categories $\mathrm{A}$ and $\mathrm{B}$. \\
\hline E3 & 2.14 & 10 & Insulation of cooling and heating distribution systems such as water pipes and canals has been done. \\
\hline \multicolumn{4}{|c|}{ Materials } \\
\hline M6 & 8.75 & 1 & Use at least $50 \%$ of construction waste to the production process and reuse them in the building \\
\hline M12 & 7.98 & 2 & Use materials that have the least environmental impact (LCA) \\
\hline M8 & 7.88 & 3 & At least $5 \%$ of non-structural building materials are recycled materials \\
\hline M4 & 7.23 & 4 & The building is designed so that at least $30 \%$ of the building skeleton can be reused \\
\hline M7 & 7.15 & 5 & At least $5 \%$ of structural concrete is made from recycled materials or green items, rubber scraps, slag, etc \\
\hline M5 & 6.77 & 6 & $\begin{array}{l}\text { At least } 5 \% \text { of the total cost of materials from renewable materials such as bamboo, fiber, chipboard, } \\
\text { straw cardboard, etc. has been used }\end{array}$ \\
\hline M10 & 6.69 & 7 & $\begin{array}{l}\text { At least } 20 \% \text { of the prefabricated elements of the building are produced off-site and in a separate } \\
\text { workshop }\end{array}$ \\
\hline M1 & 6.33 & 8 & At least $50 \%$ of the building materials are procured at a maximum distance of $800 \mathrm{~km}$ \\
\hline M2 & 6.15 & 9 & $\begin{array}{l}\text { Building materials are prepared based on modeling different parts of the building and have a valid } \\
\text { standard }\end{array}$ \\
\hline M9 & 5.1 & 10 & At least $50 \%$ of the wood materials used in the building are sustainable and licensed forest products \\
\hline
\end{tabular}




\begin{tabular}{|c|c|c|c|}
\hline M3 & 4.1 & 11 & In the design of the building, a false roof and a duct have been used to pass the installation pipes \\
\hline M11 & 3.88 & 12 & Provide plans that allow the development or change of the architectural layout of the building in the futur \\
\hline \multicolumn{4}{|c|}{ Indoor Quality } \\
\hline $\mathbf{I 1 7}$ & 14.64 & 1 & Hot and cold thermal zoning is designed and implemented for all parts of the building \\
\hline I16 & 13.19 & 2 & $\begin{array}{l}\text { There is adequate heating equipment to achieve the desired temperature of residents in summer and } \\
\text { winter }\end{array}$ \\
\hline I8 & 12.35 & 3 & Lighting control by different areas as a remote control or automatic control system \\
\hline I4 & 12.41 & 4 & All parts of the building have adequate daylight \\
\hline $\mathbf{I 1 5}$ & 12.31 & 6 & For proper ventilation, the window open space is designed for at least one-eighth of the room space \\
\hline I6 & 11.69 & 7 & At least $60 \%$ of the interior of the building has a direct and unmediated view to the outside \\
\hline I19 & 11.63 & 5 & Telephone and internet connections and access to fiber optic network are available in each room \\
\hline I13 & 11.14 & 8 & Natural or mechanical ventilation design is done for all residential spaces (mandatory) \\
\hline I14 & 10.9 & 9 & $\begin{array}{l}\text { Selected from the air conditioning system to reduce the vertical distribution of temperature and air } \\
\text { velocity in the room }\end{array}$ \\
\hline $\mathbf{I}$ & 10.48 & 10 & The building is equipped with carbon dioxide warning devices inside the building \\
\hline $\mathbf{I 1 1}$ & 10.32 & 11 & Suitable materials have been used to create sound and heat insulation in the walls and floors \\
\hline $\mathbf{I 3}$ & 10.23 & 12 & The building is located away from noise-sensitive areas and is at least 800 meters away \\
\hline $\mathbf{I 1 0}$ & 9.48 & 13 & Air inlets are located away from pollution sources and away from sewage outlets \\
\hline I18 & 8.67 & 14 & Appropriate security measures such as installing CCTV cameras are designed for the building \\
\hline $\mathbf{I 1 2}$ & 6.86 & 15 & All areas of the building are equipped with fire alarm and extinguishing system (mandatory) \\
\hline I9 & 6.75 & 17 & Intelligent or sensor lighting has been used for the common areas of the building \\
\hline I1 & 6.62 & 16 & Interior paints, adhesives and sealants comply with the standard for volatile organic compounds \\
\hline 17 & 6.03 & 18 & $\begin{array}{l}\text { Facade lighting from the top to the bottom of the building is minimized and all external lighting (except } \\
\text { safety and security lighting) is automatically turned off between } 11 \mathrm{pm} \text { and } 7 \mathrm{am}\end{array}$ \\
\hline I5 & 4.33 & 19 & Sunlight is controlled by conventional curtains or in the advanced type by automatic curtains \\
\hline
\end{tabular}

Note: F.= Friedman test; R.= rank; Cronbach's Alpha $=0.715$

272 Based on the results from the Friedman test for each dimension, facility access items (S2) for the site 273 dimension, water consumption management (W1) for the water dimension, energy consumption 274 management (E1) for the energy dimension, construction waste recycling (M6) for the material 275 dimension and thermal zoning (I17) for the indoor quality dimension have obtained the highest 276 scores in their respective dimensions. In the second stage, in order, Friedman test was re-formed 277 based on a total of 67 evaluation indicators to identify and assess the significance of each item in the 278 whole green standard, the results of which determined that the parameters of energy management 279 (E1) with a score of 53.48, renewable energy (E6) with a score of 50.72, thermal zoning (M6) with a score of 48.44 and the proximity of the building to the service centers with a score of 48.25 have achieved the highest overall scores among all the parameters of the local green standard. The results for the top 10 parameters are shown in Figure 3. 


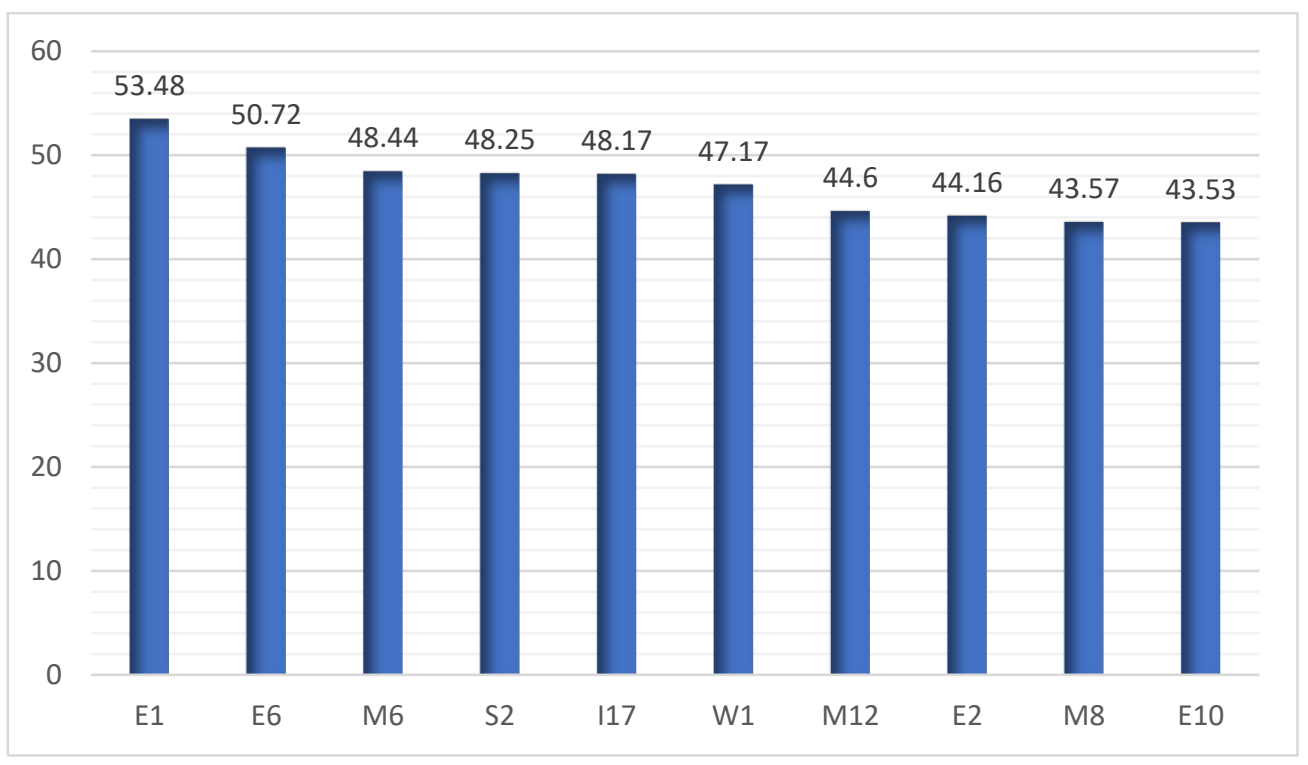

Figure 3: The most important items of national green standard in Iran

286 4. Numerical results

287 4.1. Principal Component Analysis

288 The principal component method is an orthogonal linear transform that transfers data to a new 289 coordinate system, such that the greatest variance of the data is formed on the first coordinate axis 290 and the second variance of the data on the second coordinate axis. Correlation of variables is the 291 prerequisite to this method which has been met in this study, and the numbers in Figure 4 indicate 292 the amount and type of correlation, while plotted histograms illustrates how the variables are 293 distributed. The highest correlation value pertains to the two variables of energy and site with 0.47 , 294 followed by energy and indoor quality with 0.45 


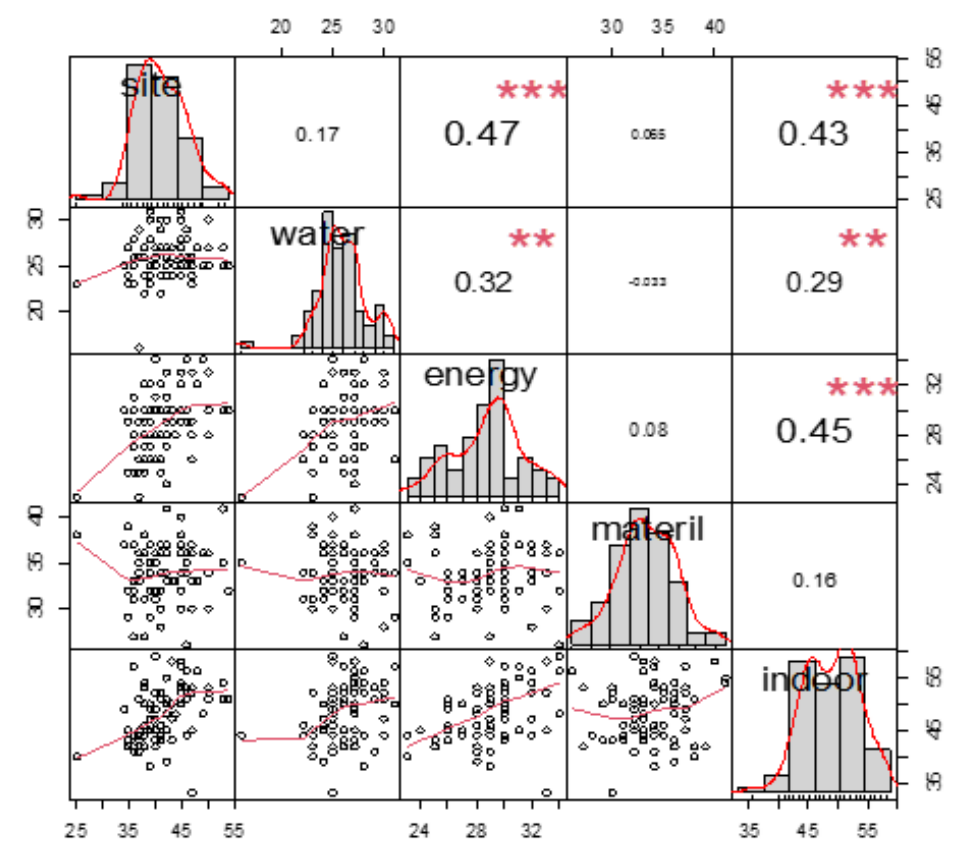

Figure 4: Histogram charts and distribution of variables in 5 standard green chapters

298 Due to the existence of a latent variable, that is, the projected green building score, only the first 299 component (PC1), which has the highest amount of variance and variability, has been used in the 300 calculations, the equation of which is as follows:

$p c 1=a_{1}$ Site $+a_{2}$ Water $+a_{3}$ Energy $+a_{4}$ Material $+a_{5}$ Indoor Quality

$\boldsymbol{a}=\left(a_{1} \cdot a_{2} \cdot a_{3} \cdot a_{4} \cdot a_{5}\right)^{T}$. s.t. $\quad \boldsymbol{a}^{T} \boldsymbol{a}=1$

303 Where $a_{j}(j=1 \ldots .5)$ are the coefficients of each dimension of green standard, and based on the 304 first component, the standard deviation is 1.4535 and the variance ratio is 0.42 . In other words, about $30542 \%$ of the total changes can be explained by the first component. To calculate the values of $a_{j}$, first 306 the data correlation matrix is formed and then the eigenvalues, eigenvectors and finally $a_{i}$ are 307 calculated using R software. The highest and lowest significance coefficients respectively pertain to 308 the energy and materials dimensions, the supplementary results of which are shown in Figure 5. 


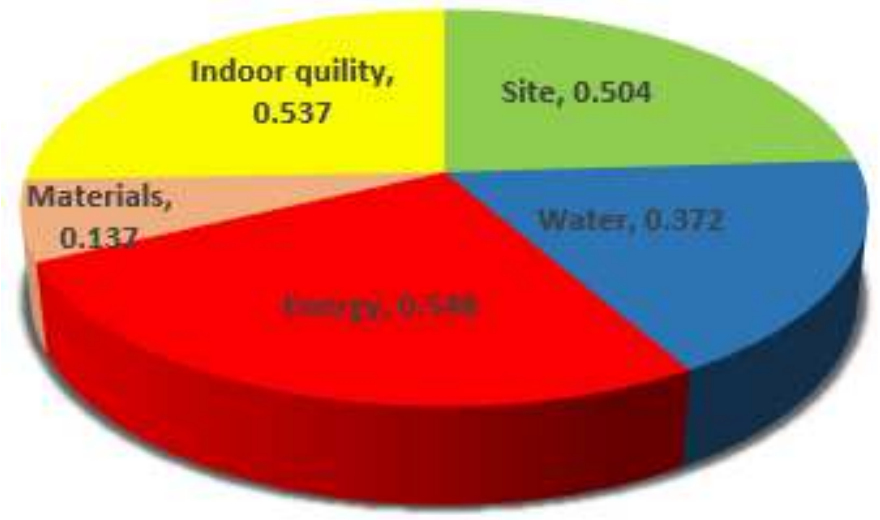

\subsection{Biplot graph}

313 Biplot is another tool to examine the significance of each green standard dimension. The numbers on 314 the graph indicate the number of the person responding to the questionnaire, in which the horizontal 315 axis represents the first component (PC1) and the vertical axis represents the second component 316 (PC2). Owing to the existence of only one dummy variable, the first component is the focal point of 317 the study, and variables that are parallel to the first component are hence considered more important. 318 According to Figure 6, the energy dimension has the highest importance, followed by the dimensions of quality of indoor environment, site, water and finally, the least importance dimension, materials.

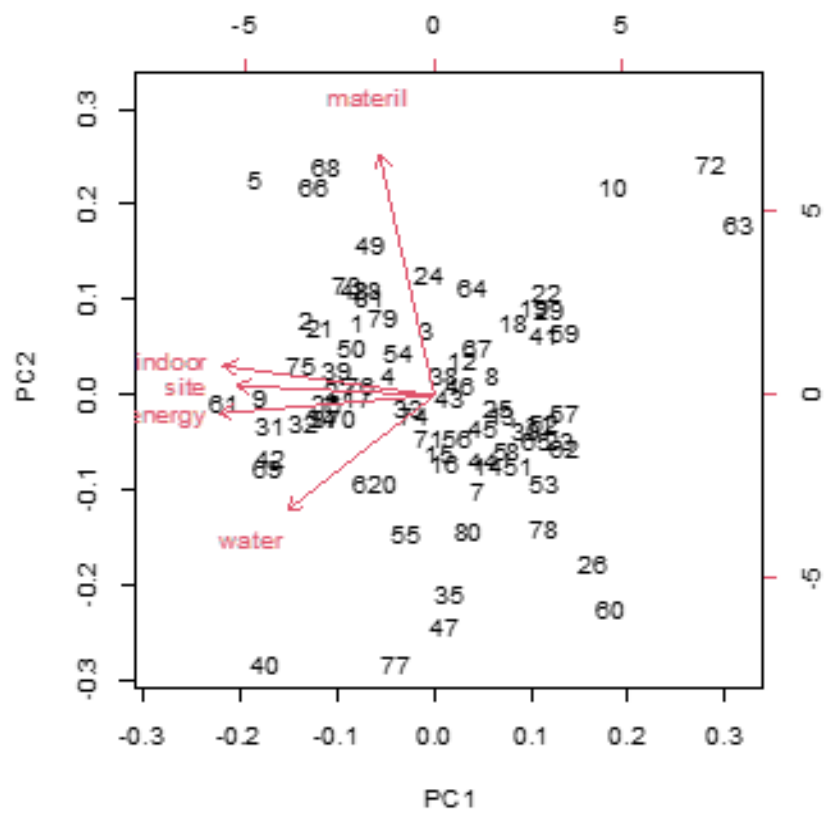




\section{4.3. Predict the national green building score}

324 After estimating the $a_{j} s$, it is necessary to calculate the scores of the first component, which the 325 general equation is as follows:

$\widehat{p c 1}=\Lambda^{-1} A^{T} x_{i}$

327 Where $\boldsymbol{\Lambda}$ is a matrix with diagonal elements of eigenvalues, $A^{T}$ is the transposition of the matrix $A$, $328 \boldsymbol{\Lambda}^{-1}$ is the inverse of $\boldsymbol{\Lambda}$ and $\widehat{p c 1}$ is the projected score of the first component per $\boldsymbol{x}_{i}$.

329 Given the existence of a principal component $\mathbf{A}_{5}=\boldsymbol{a}$ and also we have:

$\boldsymbol{x}_{\boldsymbol{i}}=\left((\text { site })_{\boldsymbol{i}} \cdot\left(\text { water }_{i} \cdot(\text { energy })_{i} \cdot(\text { material })_{i} \cdot(\text { Indoor Quality })_{i}\right)^{T} . i=1 \ldots . .81\right.$

331 To predict the green building score, there are many options for central criteria and scatter, such as 332 median, mode, variance, standard deviation, minimum, etc., but given that the central indicators are 333 numbers that are usually located around the center of many curves, so the most appropriate The 334 option for this is to use the mean (or expected value) of the central index, which is used in this study 335 according to the following formula:

$336 \widehat{\overline{p c 1}}=\boldsymbol{\Lambda}^{-1} \Lambda^{T} \overline{\boldsymbol{x}}$

$337 \overline{\boldsymbol{x}}$ is calculated using Equation 6, in which $\overline{\text { site }}$ is the average for the site variable, $\overline{\text { water }}$ is the 338 average for the water variable, $\overline{\text { energy }}$ is the average of the energy variable, $\overline{\text { material }}$ is the average for the material variable and $\overline{\text { Indoor Quality }}$ is the average of the indoor quality variable.

$340 \overline{\boldsymbol{x}}=(\overline{\text { site }} \cdot \overline{\text { water }} \cdot \overline{\text { energy }} \cdot \overline{\text { material }} \cdot \overline{\text { Indoor Quality }})^{T}$

341 Finally, $\widehat{\overline{p c 1}}$ is the estimated score for the national green building standard based on the average of 342 the variables, which is calculated to be 77.2088 using $\mathrm{R}$ software with an error of 0.2387 . 
344 The basis of the rating for the proposed green standard was on the US LEED standard rating pattern, 345 such that in the local standard, a building with a green score of 30 to 38 (40 to 49\%) receives a 346 certification, 39 to 45 (50 to 59\%) would result in a silver certification, green buildings with scores 347 of 46 to 61 points (60 to $79 \%$ ) are awarded the gold certificate, while those with scores of 62 to 77 348 (80 to $100 \%)$ are awarded the platinum certificate.

\section{5. Conclusion}

350 The development of green buildings has garnered a high level of global attention in recent years, mainly owing to limited resources and high energy consumption and, as such, various standards have been developed to this end. Nevertheless, Iran is yet to develop a local green standard, and despite high fossil fuel consumption within the country, green buildings are still highly neglected. The current study sough to identify the parameters of the national green standard, as well as the obstacles and opportunities for the implementation of green buildings, with the aim of contributing to the development of green buildings. The study was performed by obtaining comments through questionnaires from 81 construction industry experts, the results of which showed that items with the topics of access to public services for the site dimension, water consumption management for the water dimension, energy consumption management for the energy dimension, construction waste recycling for the materials dimension, and thermal zoning for indoor quality dimension achieved the highest scores in each dimension. Also, lack of awareness on green buildings and renewable energy potential obtained the highest scores respectively among the obstacles and opportunities for green buildings. Using the machine learning method and multivariate analysis, the total score of the local green building standard was predicted and calculated to be 77.2 , on which the energy dimension had the most and the materials dimension had the least impact among the five dimensions of the local green standard. A building with a score of at least $40 \%$ is considered green in this standard, and, 
silver, gold and platinum certifications are handed out based on the scores obtained in different 368 categories.

369 Findings of this study can contribute to knowledge of green building localization in Iran and can 370 have implications for contractors, investors and decision makers in the construction and energy 371 sector with the aim of paving the way for development of green buildings. It can also pose as a useful 372 reference for international organizations seeking to develop solutions to alleviates obstacles to and 373 increase the potential of green buildings.

374 Although research objectives were mostly achieved, but this study has remarkable limitations and 375 weaknesses. First, although the size of samples was sufficient for statistical analysis, increasing the 376 number of samples for future studies can enhance the quality of findings. Secondly, since in this 377 article, only the parameters and scores of the national green standard have been examined, as future 378 research avenue in Iran and other countries with similar climatic conditions, case studies of green 379 buildings can be conducted using the proposed green standard.

\section{Declarations}

381 Ethics Approval: Not Applicable

382 Consent to Participate: Not applicable

383 Consent to Publish: Not applicable

384 Authors' Contributions: Conceptualization: [Mohamad Rajabi, Javad Majrouhi Sardroud];

385 Methodology: [Mohamad Rajabi, Javad Majrouhi Sardroud];

386 Writing -original draft preparation: [Mohamad Rajabi, Ali Kheyroddin];

387 Writing -review and editing: [Javad Majrouhi Sardroud];

388 Resources: [Mohamad Rajabi];

389 Supervision: [Javad Majrouhi Sardroud; Ali Kheyroddin]. 
Funding: No fund received

Competing Interests: The authors declare that they have no competing interests

Availability of data and materials: Data can be made available on request

References

Alyami SH, Rezgui Y, (2012) Sustainable building assessment tool development approach, Sustainable Cities and Society, 5, 52-62

Babahaji Meibodi A, (2015), On-site concrete waste minimisation in Iran, ethos.bl.uk

Balaban O, Oliveira JAP, (2017), Sustainable Buildings for Healthier Cities: Assessing the Cobenefits of Green Buildings in Japan, Journal of Cleaner Production, 163, S68-S78

Chan APC, Darko A, Olanipekun AO, Ernest Effah Ameyaw, (2018), Critical barriers to green building technologies adoption in developing countries: The case of Ghana, Journal of Cleaner Production, 172, 1067-1079

Chen M, Chen JG, Cheng XX, (2011), Life Cycle Incremental Cost-Benefit Analysis of Green Building, Applied Mechanics and Materials, 71, 4645-4651

Darko A, Chan APC, (2016), Critical analysis of green building researchtrend in construction, Habitat International, 57, 53-63

Darko A, Chan APC, (2017), Review of Barriers to Green Building Adoption, Sustainable Development, 25, 167-179

Ding Z, Zhu M, Tam VWY, Yi G, Tran CNN, (2018), A system dynamics-based environmental benefit assessment model of construction waste reduction management at the design and construction stages, Journal of Cleaner Production, 176, 676-692

Doan DT, Ghaffarian hoseini A, Naismith N, Zhang T, Ghaffarian hoseini A, Tookey J, (2017), A critical comparison of green building rating systems, Building and Environment, 123, 243260 
Dwaikat LN, Ali KN, (2016), Green Building Cost Premium: A Review of Empirical Evidence, Energy and Building, 110, 396-403

Dwaikat LN, Ali KN, (2018), Green Buildings Life Cycle Cost Analysis and Life Cycle Budget Development: Practical Applications, Journal of Building Engineering, 18, 303-311

Ebadati M, Ehyaei MA, (2018), Reduction of energy consumption in residential buildings with green roofs in three different climates of Iran, Advances in Building Energy Research, 14, 66-93

Eghbali SR, Azizzadeh Araee R, Mofrad Boushehri A, (2019), Construction Waste Generation in the Iranian Building Industry, Civil Engineering Infrastructures Journal, 52, 1-10

Eliasa EM, Lin CK, (2015), The Empirical Study of Green Buildings (Residential) Implementation: Perspective of House Developers, Procedia Environmental Sciences, 28, 708-716

Energy Information Administration (EIA) website 〈www.eia.doe.gov/iea)

Esa bin MR, Marhani MA, Yaman R, Noor, Adnan H, (2011), Obstacles in Implementing Green Building Projects in Malaysia, Australian Journal of Basic and Applied Sciences, 5(12), $1806-1812$

Everitt B, Hothorn T, (2011), An Introduction to Applied Multivariate Analysis with

R. Springer, New York Dordrecht, Heidelberg, London

Ghorashi AH, Rahimi A, (2011), Renewable and non-renewable energy status in Iran: Artofknowhowand technology-gaps, Renewable and Sustainable Energy Reviews, 15, 729-736

Gou Z, Xie X, (2017), Evolving green building: triple bottom line or regenerative design?, Journal of Cleaner Production, 153, 600-607

Hedaoo MN, Khese SR, (2016), A Comparative Analysis of Rating Systems in Green Building, International Research Journal of Engineering and Technology, 03, 1393-1399

Hosseini SE, Andwari AM, Wahid MA, Bagheri G, (2013), A review on green energy potentials in Iran, Renewable and Sustainable Energy Reviews, 27, 533-545 
Huo X, Yu ATW, (2017), Analytical Review of Green Building Development Studies, Journal of Green Building, 2(12), 130-148

Hwang BG, Tan JS, (2012), Green Building Project Management: Obstacles and Solutions for Sustainable Development, Sustainable Development, 20, 335-349

International Energy Agency (IEA) website 〈www.iea.org/ Data and Statistics〉

International Renewable Energy Agency (IRENA) website〈www.irena.org/Statistics 〉

Khot Prof. Sainand, Raut R, Choudhari D, Shubhangi P, Amit J, (2019), Comparison Study between Conventional Building and Sustainable Green Building, International Journal for Research in Applied Science and Engineering Technology, 7, 3622-3623

Khozeymehnezhad H, Tahroudi MN, (2019), Annual and seasonal distribution pattern of rainfall in Iran and neighboring regions, Arabian Journal of Geosciences, 271, 1-11

Kim JL, Greene M, Kim S, (2014), Cost Comparative Analysis of a New Green Building Code for Residential Project Development, Journal of Construction Engineering and Management, $140,(140021-2)-(140021-10)$

Lee S, Lee B, Kim J, Kim J, (2013), A Financing Model to Solve Financial Barriers for Implementing Green Building Projects, the Scientific World Journal, 1-10

Li Y, He B, Zhao D, (2014), Green building in China: Needs great promotion, Sustainable Cities and Society, 11, 1-6

MacNaughton P, Cao X, Buonocore J, Cedeno-Laurent J, Spengler J, Bernstein A, Allen J, (2018), Energy savings, emission reductions, and health co-benefits of the green building movement, Journal of Exposure Science \& Environmental Epidemiology, 28(4), 307-318

Mattoni B, Guattari C, Evangelisti L, Bisegnaa F, Gori P, Asdrubali F, (2018), Critical review and methodological approach to evaluate the differences among international green building rating tools, Renewable and Sustainable Energy Reviews, 82, 950-960 
462 Meron N, Meir IA, (2017), Building green schools in Israel costs, economic benefits and teacher satisfaction, Energy and Building, 154, 12-18

Mirzaei M, Bekri M, (2017), Energy consumption and CO2 emissions in Iran, 2025, Environmental Research, 154, 345-351

Moshiri S, Atabi F, Panjehshahi MH, Lechtenböhmer S, (2012), Long run energy demand in Iran: a scenario analysis, International Journal of Energy Sector Management, 6, 120-144

Mosly I, (2015), Barriers to the Diffusion and Adoption of Green Buildings in Saudi Arabia, Journal of Management and Sustainability, 5(4), 104

Mousavi B, Lopez NSA, Biona JBM, Chiu ASF, Blesl M, (2017), Driving forces of Iran's CO2 emissions from energy consumption: an LMDI decomposition approach, Applied Energy, 206, 804-814

Najafpoor AA, Zarei A, Jamali F, Vahedian M, Zarei A, (2014), A Study Identifying Causes of Construction Waste Production and Applying Safety Management on Construction Site, Iranian Journal of Health Sciences, 2(3), 49-54

Nangare PP, Chandrakant PG, Warudkar A.A, (2015), Evaluation of Green Building with Resources and Cost Aspects, International Journal On Recent and Innovation Tends in Computing and Communication, 3, 127-130

Neyestani B, (2017), A Review on Sustainable Building (Green Building), SSRN, 1-9

Nguyen HT, Skitmore M, Gray M, Zhang X, Ayokunle Olubunmi Olanipekuna, (2017), Will green building development take off? An exploratory study of barriers to green building in Vietnam, Resources Conservation and Recycling, 127, 8-20

Nikmehr B, Hosseini MR, Oraee M, Chileshe N, (2015), Major Factors Affecting Waste Generation on Construction Sites in Iran, International Conference on Engineering, Project, and Production Management, 528-536 
Qifa J, (2013), Economic Analysis on Chinese Green Building in the Context of Life Cycle Costing, 6th International Conference on Information Management, Innovation Management and Industrial Engineering

Samari M, Godrati N, Esmaeilifar R, Olfat P, Shafiei MWM, (2013), The Investigation of the Barriers in Developing Green Building in Malaysia, Modern Applied Science, 7, 1-10

Sameei G, (2012), An Investigation of the Unemployment of Higher Educated Manpower in Iran, International Journal of Human Resource Studies, 2, 142-154

Sánchez Cordero A, Gómez Melgar S, Manuel Andújar Márquez J, (2019), Green Building Rating Systems and the New Framework Level(s): A Critical Review of Sustainability Certification within Europe, Energies, 13, 66

Sarwar S, Alsaggaf MI, (2020), The willingness and perception of people regarding green roofs installation, Environmental Science and Pollution Research, 27, 25703-25714

Shan M, Liu WQ, Hwang BG, Lye JM (2020), Critical success factors for small contractors to conduct green building construction projects in Singapore: identification and comparison with large contractors, Environmental Science and Pollution Research, 27, 8310-8322

Shen W, Tang W, Siripanan A, Lei Z, Duffield CF, Hui FKP, (2018), Understanding the Green Technical Capabilities and Barriers to Green Buildings in Developing Countries: A Case Study of Thailand, sustainability, 10(10), 3585

Sinha A, Gupta R, Kutnar A, (2013), Sustainable Development and Green Buildings, Drvna Industrija, 64(1), 45-53

Soleymani B, Nik Nafs J, (2017), Evaluate and Prioritize the Factors Affecting the Project Cost Construction and Friedman Test Using a Special Vector, International Research Journal of Applied and Basic Sciences, 11(1), 87-94 
509 Taghvaee VM, Mavuka C, Shirazi JK, (2017), Economic growth and energy consumption in Iran: an 510 ARDL approach including renewable and non-renewable energies, Environment, Development and Sustainability, 19, 2405-2420

512 Uğur LO, Leblebici N, (2018), An examination of the LEED green building certification system in 513 terms of construction costs, Renewable and Sustainable Energy Review,1476-1483

514 Zhang L, Wu J, Liu H, (2018), Turning green into gold: A review on the economics of green buildings, Journal of Cleaner Production,172, 2234-2245

516 Zhang Y, Wang J, Hu F, Wang Y, (2017), Comparison of evaluation standards for green building in China, Britain, United States, Renewable and sustainable energy,68, 262-271

518 Zhao X, Zuo J, Wu G, Huang C, (2019), A bibliometric review of green building research 2000519 2016, Architectural Science Review, 62, 74-88

520 Zuo J, Pullen S, Rameezdeen R, Bennetts H, Wang Y, Mao G, Zhou Z, Du H, Duan H, (2017), 521 Green building evaluation from a life-cycle perspective in Australia: A critical review, Renewable and Sustainable Energy Reviews, 70, 358-368

523 Zuo J, Zhao ZY, (2014), Green building research-current status and future agenda: A review, 524 Renewable and Sustainable Energy Reviews, 30, 271-281 
Figures

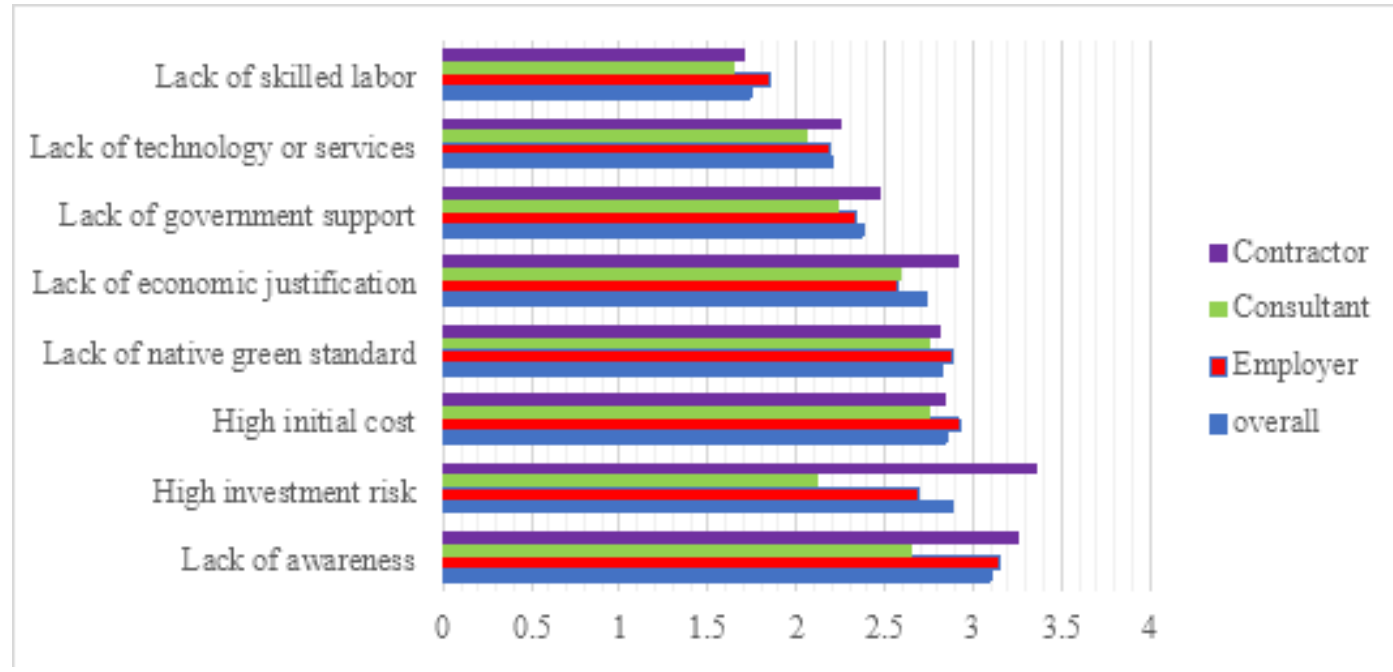

Figure 1

Obstacles to the implementation of green buildings in Iran

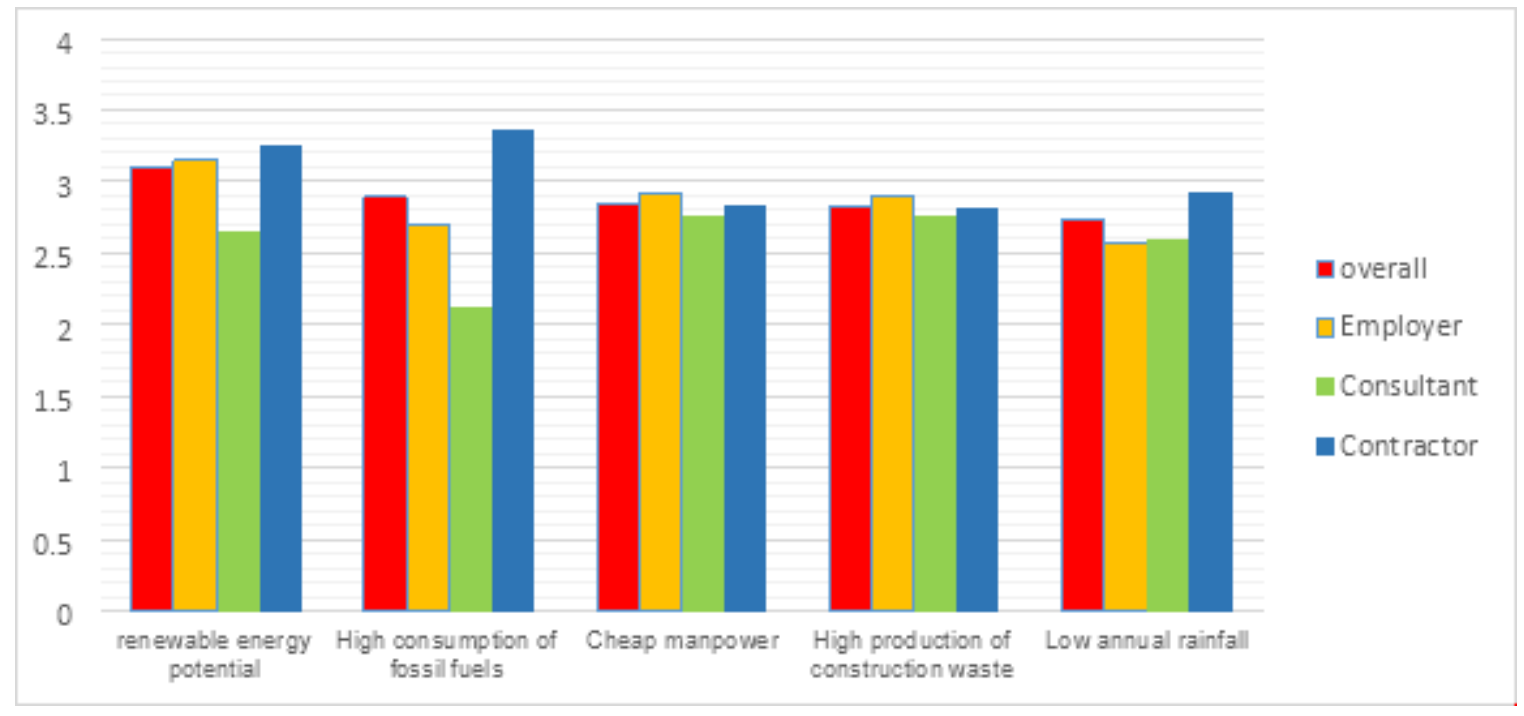

Figure 2

Opportunities or necessities of implementing green buildings in Iran 


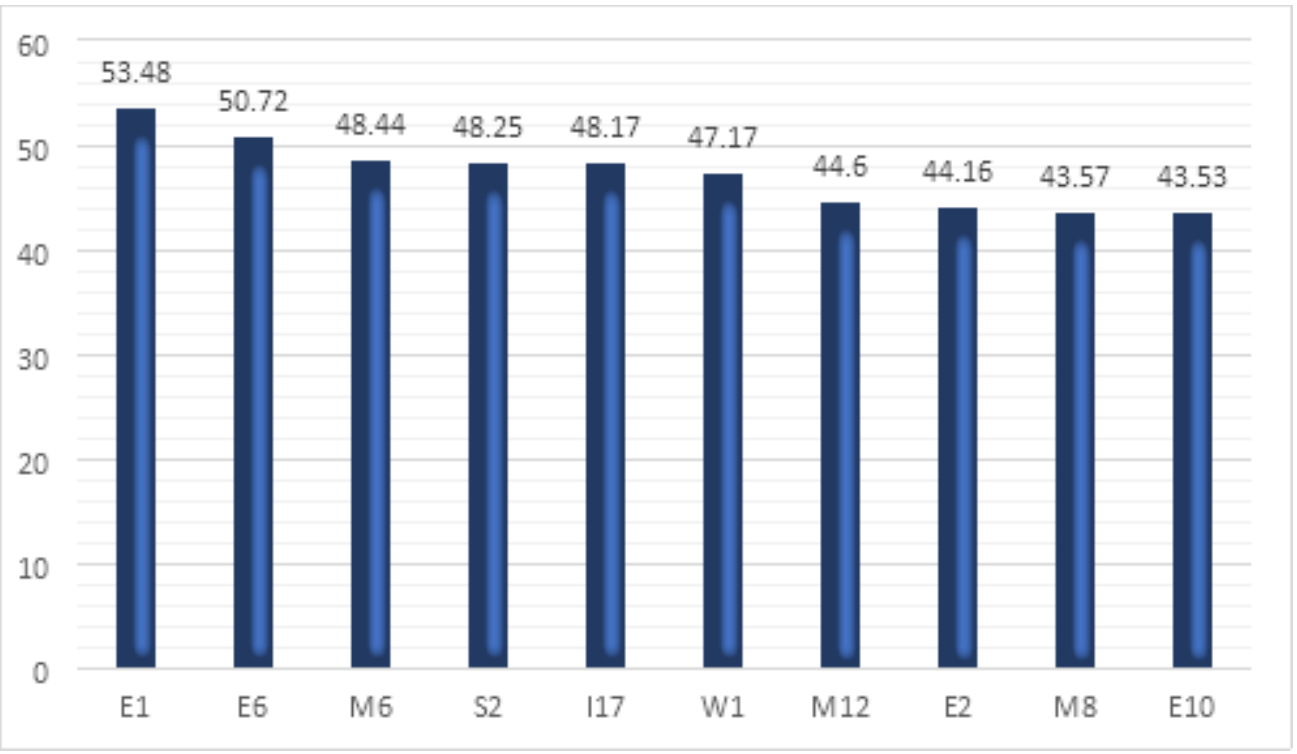

Figure 3

The most important items of national green standard in Iran

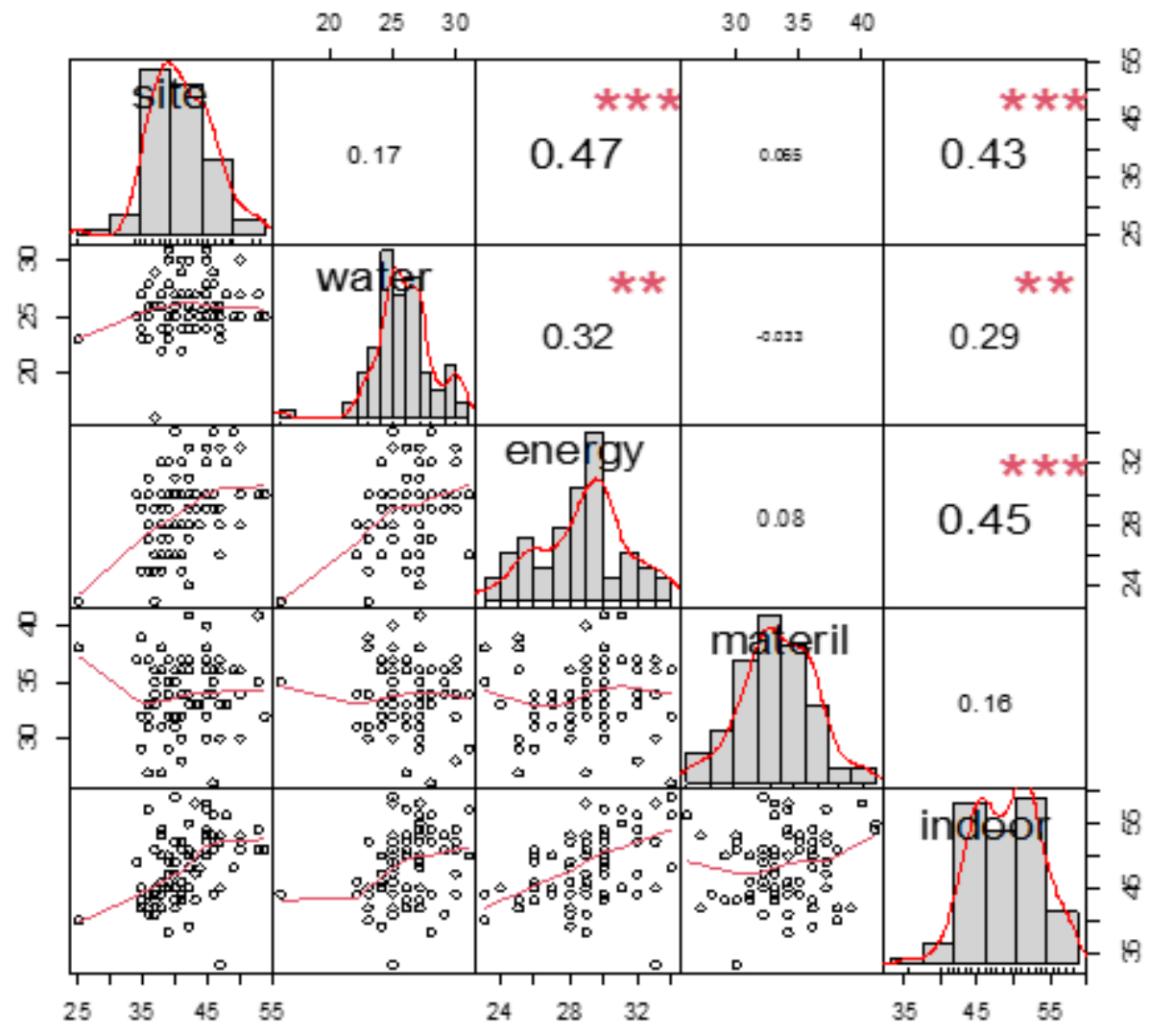

Figure 4

Histogram charts and distribution of variables in 5 standard green chapters 


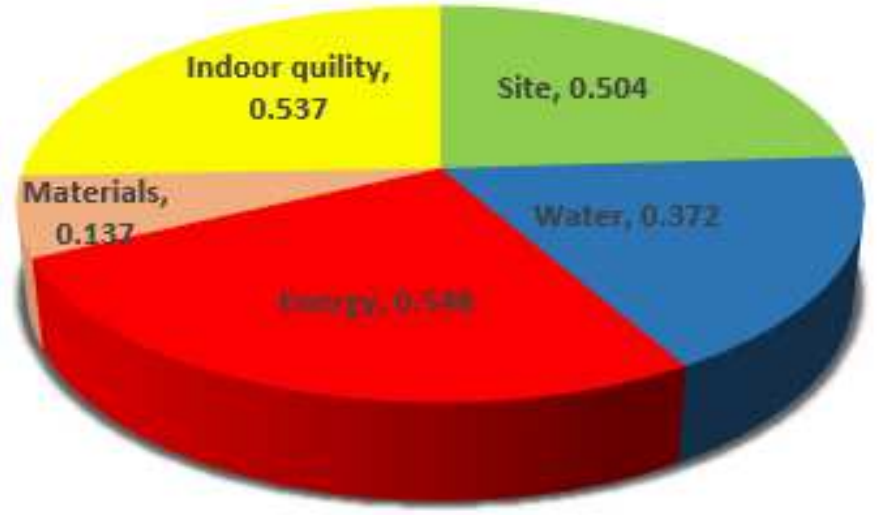

Figure 5

Significance coefficients of 5 Green Standard dimensions

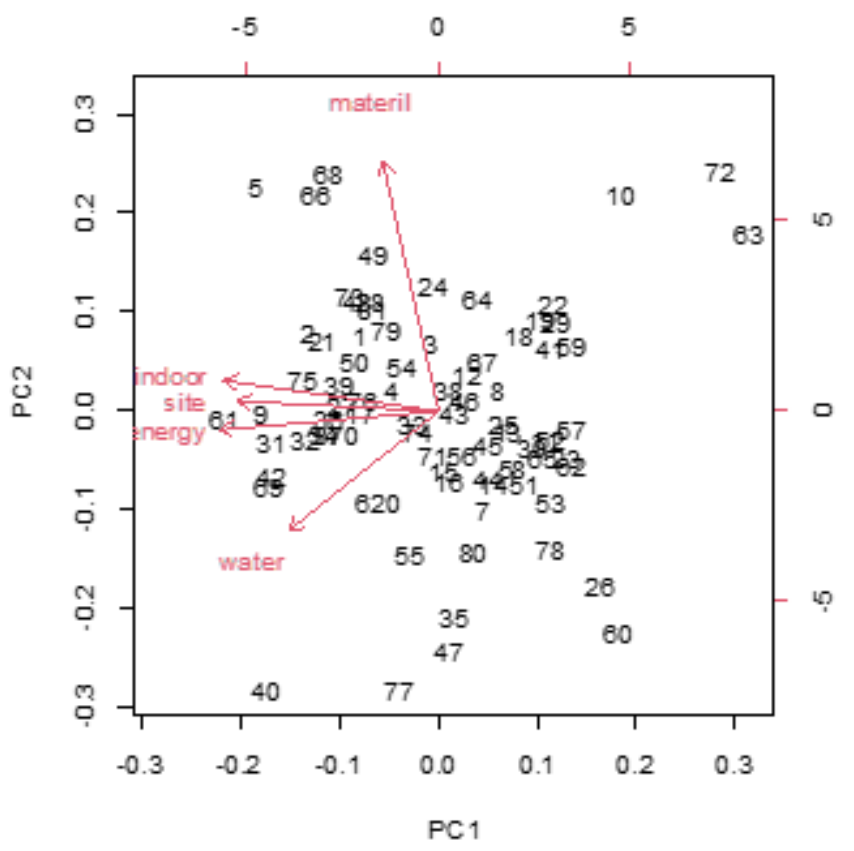

Figure 6

Significance of each of the standard green seasons based on the Biplot graph 